\title{
THE USE OF GOOGLE CLASSROOM AS AN EDUCATIONAL TOOL FOR THE LEARNING OF RHEUMATOLOGY IN ACADEMIC GRADUATION DURING THE COVID-19 PANDEMIC
}

\author{
Adah Sophia Rodrigues Vieira ${ }^{1}$, Ana Natália Vasconcelos Arcanjoํㅗ Priscila Dourado Evangelista1,* \\ 1.Universidade de Fortaleza, Fortaleza (CE), Brazil. \\ ${ }^{\star}$ Corresponding author: prisdourado@yahoo.com.br
}

\section{BACKGROUND}

During the COVID-19 pandemic, there was a need to reinvent the process of learning and teaching, especially having the social distance and the quarantine as the most effective methods in controlling the virus transmission. In this scenario, the application of digital tools in medical schools became essential for promoting good quality, not just in teaching manner, but in earning too. Therefore, this study has the objective to analyze the use of Google Classroom in the study of rheumatology for the academic students of medicine during the COVID-19 pandemics.

\section{METHODS}

Cross-sectional and quantitative study, that analyzes 60 medical students that had used the platform Google Classroom in the study of rheumatology. Within the platform, videos and didactic material, like flashcards and questions, were posted, following the discipline chronogram, in order to help the students study and review the content. The data was obtained through a questionnaire, sent via WhatsApp, with six objective questions about their experience during the use of the digital tool and whether the instrument was helpful or not, regarding their personal learning of rheumatology. All students responded anonymously, and also signed a term of consent that the results of the form could be used in future research.

\section{RESULTS}

From the 96 students that attended this module, 60 answered the questionnaire. About $95 \%$ assured that the platform improved their learning process, especially regarding the videos (86.7\%) and the flashcards (80\%). Some students claimed they had some difficulties regarding the use of the platform, such as demotivation (18.3\%) and lack of time (35\%), but the majority claimed that they had no difficulties at all (56.7\%). About $96.7 \%$ of them evaluated the platform, on a scale of 0 to 10 , as higher than 8 , in which $80 \%$ gave the maximum score.

\section{CONCLUSION}

The need to reinvent the process of learning and teaching made possible for some means and platforms that were not used much before to establish a part in medical education. The Google Classroom platform has proven to be extremely effective for the learning of rheumatology, not just because of its accessible design, but also because of its many possibilities of improving education.

\section{KEYWORDS}

Google classroom, Educational tool, COVID-19 pandemic. 